\title{
The Influence Of Job Placement, Job Rotation And Organizational Culture Toward Job Satisfaction And Its Impact To The Performance Of Employees Department Of Mines And Energy Aceh
}

\author{
Zahriatul Aini ${ }^{1 *}$, Salima Ihsani ${ }^{2}$, Sisca Mediyanti ${ }^{3}$, Agustina $^{4}$, Mirnawati ${ }^{1}$ \\ \{*zahriatulaini@poltekkutaraja.ac.id\} \\ ${ }^{\text {I}}$ Office Administration Department, Politeknik Kutaraja, Banda Aceh, Indonesia \\ ${ }^{2}$ Management Department, Universitas Syiah Kuala, Banda Aceh, Indonesia \\ ${ }^{3}$ Accounting Department, Politeknik Kutaraja, Banda Aceh, Indonesia \\ ${ }^{4}$ Financial Analys Department, Politeknik Kutaraja, Banda Aceh, Indonesia
}

\begin{abstract}
Some of the factors that affect the performance of employees at the Department of Mines and Energy of Aceh among others are the ineffectiveness of job rotation applied at the Department of Mines and Energy of Aceh, the incompatibility of work placements undertaken leadership and inappropriate organizational culture that is created in the Department of Mines and Energy Aceh. These have caused the decrease of job satisfaction. The reduction of employee's satisfaction will influence their working performance. Lack of innovation, creativity and collaboration among the employees in task completions indicates unfavorable organizational culture and working environment with low level of motivation with which affect their working performances. From 7 tested hypothesis, all are qualified and accepted, because the pick p value is below 0.05. However, there are different effects to predicted variables. The direct effect of Organizational Culture variable employee performance is 0.606 . While variable influence of organizational culture on the employee performance through the variable of job satisfaction is 0.045 . The direct influence of Placement variable on employee performance is 0.274. Meanwhile, the placement variable influences on employee performance of the Department of Mines and Energy through the variable of job satisfaction is 0.054 .
\end{abstract}

Keyword : Placement, Retation, Satisfaction

\section{Introduction}

At the Department of Mines and Energy of Aceh has it seen many employees who completed the work not on time, and most of them spend time relaxing, this is caused by a lack of knowledge and ability of employees to analyze a job so that they had difficulty to be able to complete the work on time appropriately and with high standard. In addition there are several factors that also affect employees performance of Department of Mines and Energy of Aceh among others. The ineffectiveness of job rotation applied in Department of Mines and Energy of Aceh, incompatibility of job placement done without high level of leadership and organizational culture that is created in Department of Mines and Energy of Aceh has negatively affect their job satisfaction. The reduction of employee satisfaction will influence 
the performance of them. Lack of innovation, creativity and orientation for collaboration among employees of the Department of Mines and Energy of Aceh in completing the tasks indicated unfavorable organizational culture and do not have a high motivation to work so that the effect on their performance. In the works are also found employees who perform repetitive work and made mistakes that should not have happened, this is due to carelessness, stability and aggressiveness of employees in completing their task, so it takes a long time for a job that should require a short time. Low levels of employee satisfaction are very closely related to employment, job rotation and an organizational culture that is still relatively not as expected. Performance (performance) is an organizational behavior that is directly related to the production of goods or delivery of services. Performance is often thought of as the achievement of the task, a task in which the term itself comes from thinking activities required by workers[1]. [2] states that job satisfaction is a person's general attitude toward his work that shows a person's suitability expectations arising in return provided by his job.[1]say that: Employment is a process assignor and employment to workers who graduated from selection to implement continuity with authority and responsibility for the portion and composition are determined and able to account for all risks and possibilities that occur, among other functions and jobs, authority and responsibilities.[2] job rotation is defined as periodic changes in workers from one task to another. In addition,[3] define job rotation as the transfer of employees from one job to another. To be effective, there must be an organizational structure that describes a clear job (job discription), authority (authority), and responsibility (accountabillity) between parts / sections within the organization and inter-personal relationships which are believed to be linking behaviors / individuals and groups in improving quality of care, thus the organizational structure greatly affect the effectiveness of the service. [4] organizational culture is a set of assumptions and beliefs held by members of the organization, then developed and passed in order to overcome the problems of external adaptation and internal integration problems. Culture basically contains the pattern explicitly or implicitly from and to the required behavior and embodied the results of groups of people differently, including objects created by men, the main core of culture consists of traditional ideas in the sense of hereditary and selected, embedded in values that accompany[1].

\section{Methodology}

Research on the Influence of Employment, job rotation and Cultural Organization on Job Satisfaction and its impact on employee performance Aceh Department of Mines and Energy was held at the Department of Mines and Energy Aceh. This research was conducted at the Department of Mines and Energy Aceh. The sampling technique in this research used census techniques. That is because the method of data analysis of this study will use the technique of structural equation modeling (SEM) which requires a minimum sample size of 100 people [5], so that the whole of the population will be a responder. The research model that will be used in this research is a tiered structure model and to test the hypothesis used technique SEM (Structural Equation Modeling), which is operated through a program AMOS 22.

\section{Result and Discussion}


The following figure shows the relationship indicators and unobserved variables (latent variables) in the Measurement Model.

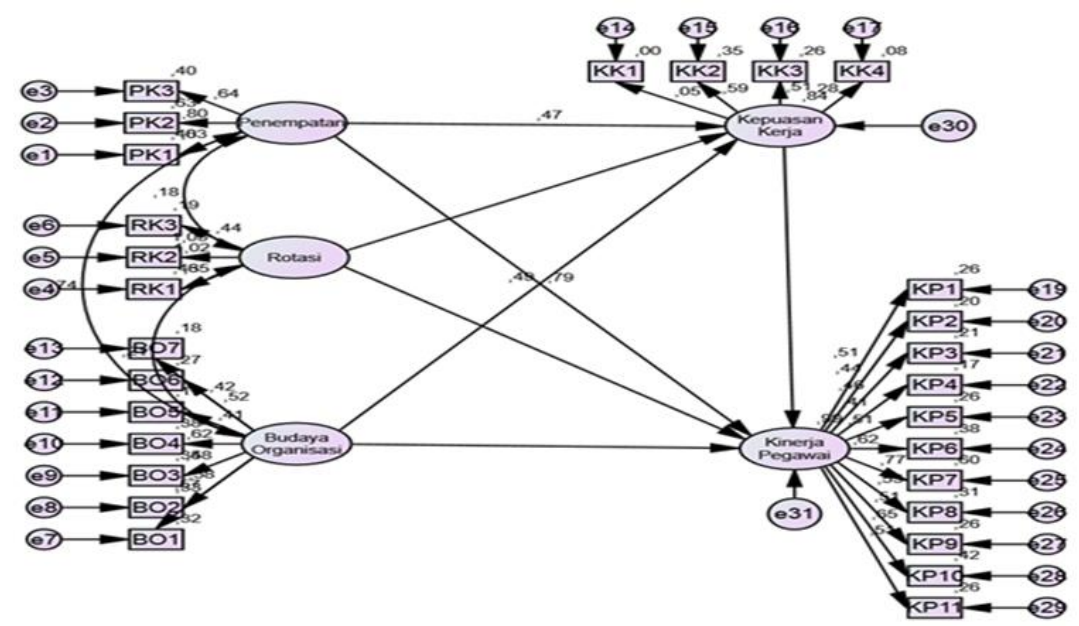

Fig1. Measurement Model of The Loading Factor

Loading factor which represents the contribution of each indicator against which the represented variable can be seen in the following table:

Table 1. Indicator Loading Factor of Variable

\begin{tabular}{lllll}
\hline No & Indicator & Effect & Variable & Estimate \\
\hline 1 & KK1 & $<--$ & Job Satisfaction & 0,524 \\
2 & KK2 & $<--$ & Job Satisfaction & 0,144 \\
3 & KK3 & $<--$ & Job Satisfaction & 0,130 \\
4 & KK4 & $<---$ & Job Satisfaction & 0,338 \\
5 & KK5 & --- & Job Satisfaction & 0,028 \\
6 & KP1 & $<--$ & Employee Performance & 0,515 \\
7 & KP2 & --- & Employee Performance & 0,441 \\
8 & KP3 & $<--$ & Employee Performance & 0,459 \\
9 & KP4 & $<---$ & Employee Performance & 0,406 \\
10 & KP5 & $<--$ & Employee Performance & 0,508 \\
11 & KP6 & $<---$ & Employee Performance & 0,615 \\
12 & KP7 & $<---$ & Employee Performance & 0,777 \\
13 & KP8 & $<---$ & Employee Performance & 0,559 \\
14 & KP9 & $<---$ & Employee Performance & 0,508 \\
15 & KP10 & $<---$ & Employee Performance & 0,647 \\
16 & Kp11 & $<---$ & Employee Performance & 0,509 \\
\hline
\end{tabular}

From Table 1 above shows that there are some indicators which do not have numbers relatively low loading factor is below 0.5 . In other words, the formation of these variables are not supported by an adequate contribution of the relevant indicators that ought to be eliminated from the model.

Tabel 2. Criteria Goodness of Fit Measurement Models 


\begin{tabular}{cccc}
\hline Index Criteria & Cu-Off Value & Analysis Result & Model Evaluation \\
\hline CIMN & CIMN/DF $>2$ & 4,267 & Good \\
Baseline & 1 & $>0,5$ for NFI, IFI, TLI, and & Very Good \\
Comparisons & $0-1$ & CFI & Good \\
Parsymony & & $\begin{array}{c}\text { Pration, PNFI, PDCFI } \\
\text { between } 0-1\end{array}$ & Good \\
Adjusted Measures & $>0,05$ & 0,180 & Good \\
RMSEA & Default Model $<$ Saturated & $648,0<1207,826<2882,471$ & 0,515 \\
AIC & Default Model Between & Employee Performance & \\
ECVI & Saturated and & & \\
& Independence & & \\
\hline
\end{tabular}

Testing this hypothesis is based on research data processing using SEM analysis, by analyzing the value of regression (Regression Weights Analysis of Structural Equation Modeling).

Table 3. Conclution of Hypotesis

\begin{tabular}{cllll}
\hline No & & Effect Between & Beta & Conclusion \\
\hline 1 & Job Placement (X1) & Job Satisfaction (Y) & 0,432 & Rejected Ho \\
2 & Job Rotation (X2) & Job Satisfaction (Y) & 0,436 & Accepted Ho \\
3 & Organization Culture (X3) & Job Satisfaction (Y) & 0,359 & Rejected Ho \\
4 & Job Placement (X1) & Employee Performance (Z) & 0,274 & Rejected Ho \\
5 & Job Rotation (X2) & Employee Performance (Z) & $-0,623$ & Accepted Ho \\
6 & Organization Culture (X3) & Employee Performance (Z) & 0,606 & Rejected Ho \\
7 & Job Satisfaction (Y) & Employee Performance (Z) & 0,125 & Rejected Ho \\
\hline
\end{tabular}

From the table 3 above shows all verification hypotheses tested to meet the requirements for admission, so it can be concluded that hypothesis 1, 3, 4, 6 and 7 is accepted. In other words, independence and intervening variables have an effect to increase the dependent variable along the independent and intervening variables can be enhanced by the manager of the Post Office in Banda Aceh. Direct and Indirect influence between variables Leadership Style, Organizational Structure and Competence of the Effectiveness of Organizational Performance are through Employee Performance variables. Influence Analysis was conducted to analyze the effect of the power of influence between direct influence indirect influence, and total effect. Direct effect is nothing but the coefficients of all the coefficients lines with an arrow in one end. Indirect effects are effects that arises through a middle variable. Total effect is the effect of the various relationships[5]. The results of the regression coefficients that have been done showed the direct influence of the various variables studied, as shown in Figure 4 below. Direct influence, indirect influence and the influence of the total shown by the relationship between the independent variables, mediating and dependent can be seen in table 4 below.

Tabel 4. Direct, Indirect and Result

\begin{tabular}{lllll}
\hline No & \multicolumn{1}{c}{ Remark } & Direct & Indirect & Result \\
\hline 1 & $\begin{array}{l}\text { To determine the effect of exogen variable to Job } \\
\text { Placement (X1) with endogen variable employee } \\
\text { performance (Z) through intervening variable Job }\end{array}$ & & & \\
& $\begin{array}{l}\text { Satisfaction (Y) } \\
\text { To determine the effect of exogen variable to }\end{array}$ & 0,606 & 0,045 & Direct> Indirect \\
$\begin{array}{l}\text { Organization Culture (X3) with endogen variable } \\
\text { employee performance (Z) through intervening } \\
\text { variable Job Satisfaction (Y) }\end{array}$ & & & \\
\hline
\end{tabular}


Direct influence between the variables that exist in this research is the $\mathrm{X} 1, \mathrm{X} 3, \mathrm{Y}$ and $\mathrm{Z}$ are comprised of variable Employment, Organizational Culture, Job Satisfaction and Employee Performance, its direct effect is greater than the indirect effect. Organizational Cultural variable direct influence on employee performance is 0.606 . While variables influence organizational culture on employee performance when the Department of Mines and Energy through the variable job satisfaction is 0.045 . This means that if you want to improve employee performance Mines and Energy Office of Aceh, it would be better if the manager of this office does not improve its performance through indicators on the Job Satisfaction of variables, but directly to the Organizational Culture indicator that gives the largest contribution to the improved performance of this organization. Placement variable direct influence on employee performance is 0.274 . While the placement of variables influence on employee performance when the Department of Mines and Energy through the variable job satisfaction is 0.054 . This means that if you want to improve employee performance Mines and Energy Office of Aceh, it would be better if the manager of this office does not improve its performance through indicators on the Job Satisfaction of variables, but the indicator Employment the largest contributors to the improved performance of this organization.

\section{Conclusion}

To improve employee performance in order to better through the influence of organizational culture, it is expected the Department of Mines and Energy of Aceh can encourage employees to work more aggressive, innovative and more willing to take risks. To improve employee performance in order to better through Employment, the Department of Mines and Energy is expected to Aceh to put their employees work in accordance with section background knowledge / education. To improve employee performance in order to better then expected the Department of Mines and Energy Aceh increase Employee Job Satisfaction by giving promotions or bonuses for employees who can complete the task well. Department of Mines and Energy of Aceh need to strive to increase the quality and quantity of work employees are still low in order to improve the performance of Mining and Energy Employees Aceh.

\section{References}

[1] Ratna Kusumawati, "Analisis Pengaruh Budaya Organisasi dan Gaya Kepemimpinan Terhadap Kepuasan Kerja Untuk Meningkatkan Kinerja Karyawan (Studi Kasus Pada RS Roemani Semarang)," vol. 3, no. 6, pp. 148-161, 2008.

[2] S. Rast and A. Tourani, "Evaluation of Employees ' Job Satisfaction and Role of Gender Difference: An Empirical Study at Airline Industry in Iran,” Int. J. Bus. Soc. Sci., vol. 3, no. 7, pp. 91-100, 2012.

[3] Tidar Pahala, "Rotasi Pekerjaan dan Kemampuan Kerja dan Berpengaruh Terhadap Kinerja Karyawan Pada Bank BJB Syariah Pusat Kota Bandung."

[4] K. Sakdiah and M. Z. Hasibuan, "Hubungan Implementasi Total Quality Management ( TQM ), Kinerja Pegawai Dengan Meningkatkan Kualitas Pelayanan Administrasi,” pp. 86-90, 2019.

[5] Muhammad Anik, "Strategi Operasi Dan Keunggulan Bersaing Untuk Meningkatkan Kinerja Perusahaan,” vol. 24, no. 1, pp. 11-25, 2015. 
